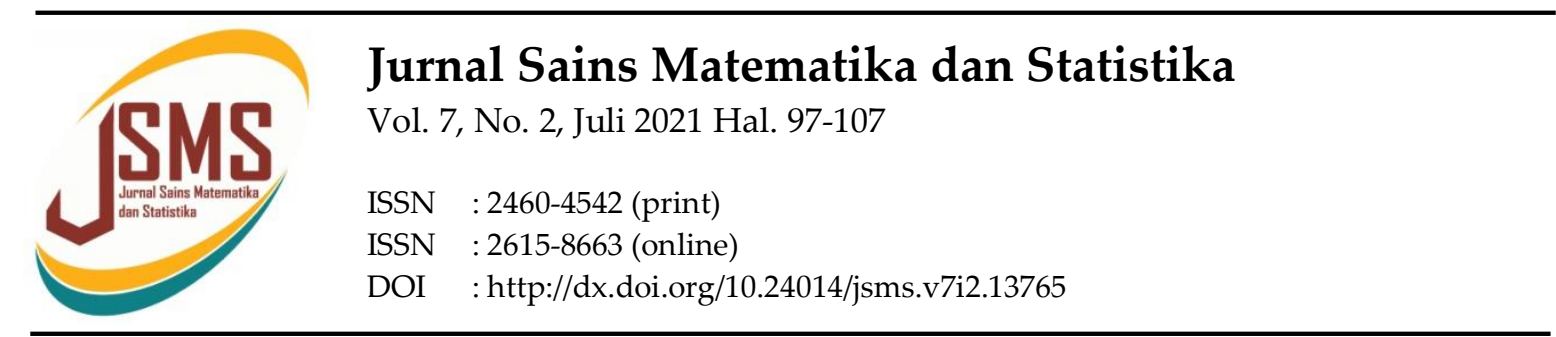

\title{
Pemodelan Vector Autoregressive (Var) untuk Data Jumlah Perceraian di Kota Pekanbaru
}

\author{
Ari Pani Desvina ${ }^{1}$, Novina Melinda ${ }^{2}$, Nilwan Andiraja ${ }^{3}$ \\ 1,2,3Program Studi Matematika, Fakultas Sains dan Teknologi, UIN Sultan Syarif Kasim Riau \\ 1,23.3. HR. Soebrantas No. 155 Simpang Baru, Panam, Pekanbaru, 28293 \\ Email: aripanidesvina@uin-suska.ac.id, novinamelinda44@gmail.com, nilwanandiraja@uin-suska.ac.id \\ *Korespondensi penulis : aripanidesvina@uin-suska.ac.id
}

\begin{abstract}
Abstrak
Perceraian merupakan terputusnya hubungan antara suami istri akibat dari kegagalan pasangan suami istri dalam menjalani peran masing-masing. Maraknya fenomena perceraian yang terjadi bisa disebabkan oleh beberapa faktor seperti faktor ekonomi, tidak harmonis dan tidak bertanggung jawab. Model Vector Autoregressive (VAR) merupakan salah satu model yang digunakan untuk menentukan peramalan dengan beberapa variabel dan berguna untuk melihat keterkaitan hubungan antar variabel. Tujuan penelitian ini yaitu untuk menentukan peramalan jumlah perceraian di Kota Pekanbaru dengan menggunakan model Vector Autoregressive (VAR). Selain menentukan peramalan jumlah perceraian, dalam penelitian ini juga menentukan factor-faktor yang menyebabkan terjadinya perceraian. Sehingga model yang sesuai digunakan untuk peramalan yang menggunakan variable lebih dari satu yaitu model Vector Autoregressive (VAR). Data yang digunakan dalam penelitian ini adalah data time series yaitu data jumlah perceraian, faktor ekonomi, tidak harmonis dan tidak bertanggung jawab di Kota Pekanbaru mulai Januari 2014 sampai Desember 2018. Hasil pembahasan yang diperoleh menunjukkan bahwa model VAR(2) adalah model yang sesuai untuk meramalkan jumlah perceraian di Kota Pekanbaru pada waktu yang akan datang. Berdasarkan hasil uji kausalitas Granger menunjukkan bahwa perceraian dipengaruhi oleh tidak harmonis, tidak harmonis dipengaruhi factor ekonomi, dan tidak harmonis dipengaruhi tidak bertanggung jawab. Sedangkan hasil peramalan jumlah perceraian di Kota Pekanbaru untuk Januari 2019 sampai Desember 2020 menunjukkan terjadinya peningkatan yang tidak berbeda jauh dari bulan sebelumnya, dengan nilai akurasi peramalannya menggunakan MAPE adalah $47,76 \%$.
\end{abstract}

Katakunci: Perceraian, Peramalan, Vector Autoregressive (VAR).

\begin{abstract}
Divorce is one of the issues that is being discussed in recent times. Oftentimes, divorce occurs caused by several factors such as economic factors, disharmonious and irresponsible. The Vector Autoregressive (VAR) model is one of the models used to determine forecasting with several variables
\end{abstract}


and use for seeing the relationship between variables. The purpose of this study is to determine the forecasting of the number of divorces in Pekanbaru City using the Vector Autoregressive (VAR) model. In addition to determining the forecasting of the number of divorces, this study also determines the factors that cause divorce. So that the appropriate model is used for forecasting that uses more than one variable, namely the Vector Autoregressive (VAR) model. The data used in this study is time series data, namely data on the number of divorces, economic factors, disharmony and irresponsibility in Pekanbaru City from January 2014 to December 2018. The results of the discussion obtained indicate that the VAR(2) model is an appropriate model to predict the number of divorces in Pekanbaru City in the future. Based on the results of the Granger causality test, it shows that divorce influenced disharmony, disharmony influenced the economy, and disharmony influenced irresponsibility. Meanwhile, the results of forecasting the number of divorces in Pekanbaru City for January 2019 to December 2020 showed an increase that was not much different from the previous month, with the forecasting accuracy value using MAPE was $47.76 \%$.

Keywords: Divorce, Forecasting, Vector Autoregressive (VAR)

\section{Pendahuluan}

Kasus perceraian selalu menjadi topik yang diperbincangkan di media sosial seperti media elektronik, media cetak ataupun media lainnya baik dikalangan artis maupun di berbagai kalangan lainnya [2]. Maraknya fenomena perceraian ini juga terjadi di Kota Pekanbaru, dimana di kota ini tingkat perceraiannya masih relatif tinggi walaupun terkadang masih mengalami fluktuasi. Tidak sedikit perceraian terjadi pada mereka yang baru berumah tangga.

Berdasarkan jumlah perkara perceraian oleh Pengadilan Agama Kelas 1A Kota Pekanbaru pada tahun 2014 sampai dengan tahun 2018 menyatakan bahwa kasus permohonan perceraian di Kota Pekanbaru mengalami peningkatan. Angka perceraian di Kota Pekanbaru Tahun 2018 diperkirakan meningkat dibandingkan tahun sebelumnya bila dilihat dari tingginya permohonan perceraian pasangan suami istri. Perceraian yang paling dominan ialah dikarenakan beberapa faktor seperti tekanan ekonomi, tidak harmonisnya suatu rumah tangga, pihak ketiga, kekerasan dalam rumah tangga serta tidak bertanggung jawabnya seorang suami didalam suatu rumah tangga. Namun dari sekian banyak permohonan perceraian tersebut faktor utama yang menjadi penyebabnya ialah akibat tekanan ekonomi.

Beberapa peneliti telah melakukan penelitian untuk memprediksi jumlah perceraian dimasa yang akan datang, seperti penelitian yang dilakukan oleh [6] dengan judul "Forecasting Jumlah Perkara Perceraian Menggunakan Single Moving Average di Pengadilan Agama Sumber". Hasil penelitiannya menunjukkan bahwa jumlah perceraian yang akan terjadi pada 4 bulan kedepan akan mengalami kenaikan bila dibandingkan dengan 3 bulan kedepan. Selanjutnya, [7] juga melakukan penelitian untuk mengetahui faktorfaktor yang mempengaruhi perceraian dengan judul "Faktor-faktor Penyebab Perceraian pada Pengadilan Agama Pariaman dengan Penerapan Metode Regresi Logistik Biner". Hasil penelitiannya menunjukkan bahwa faktor-faktor yang lebih berpengaruh terhadap perceraian adalah tingkat pendidikan suami dan tidak ada keharmonisan.

Berdasarkan penjelasan diatas, maka perlu dilakukan prediksi tentang data jumlah perceraian beserta faktor-faktor yang mempengaruhinya untuk periode mendatang. Prediksi untuk data jumlah perceraian, faktor ekonomi, tidak harmonis dan tidak ada 
tanggung jawab dapat dilakukan dengan model runtun waktu tunggal (univariat) dan dapat juga dilakukan secara bersamaan (multivariat). Dalam hal ini penulis menggunakan model yang berbeda dari penelitian sebelumnya, salah satu metode peramalan yang dapat digunakan dalam model bersama yaitu dengan model Vector Autoregressive (VAR).

\section{Metode Penelitian}

\subsection{Landasan Teori}

\subsubsection{Definisi Analisis Runtun Waktu}

Data time series adalah jenis data yang disusun menurut urutan waktu dalam suatu rentang waktu tertentu. Dapat berupa detik, menit, jam, hari, minggu, bulan atau tahun. Analisis runtun waktu merupakan salah satu prosedur statistika yang diterapkan untuk meramalkan struktur probabilitas keadaan yang akan datang dalam rangka pengambilan keputusan. Dasar pemikiran runtun waktu adalah pengamatan sekarang dipengaruhi oleh satu atau beberapa pengamatan sebelumnya [5].

\subsubsection{Vector Autoregressive (VAR)}

Vector Autoregressive (VAR) merupakan suatu sistem persamaan yang memperlihatkan setiap variabel sebagai fungsi linear dari konstanta dan nilai lag dari variabel itu sendiri, serta nilai lag dari variabel lain yang ada dalam model. Definisi dari model VAR adalah semua variabel yang ada di dalam model VAR adalah endogeneous. Secara umum model VAR lag $p$ untuk $n$ peubah dapat diformulasikan sebagai berikut [1] :

$$
Y_{t}=A_{0}+A_{1} Y_{t-1}+A_{2} Y_{t-2}+\cdots+A_{p} Y_{t-p}+e_{t}
$$

Model dari Vector Autoregressive (VAR) yang terdiri dari dua variabel dan 1 lag adalah: $\operatorname{VAR}(1)$ :

$$
\begin{aligned}
& Y_{t}=a_{10}+a_{11} Y_{t-1}+a_{12} X_{t-1}+e_{1 t} \\
& X_{t}=a_{20}+a_{21} Y_{t-1}+a_{22} X_{t-1}+e_{2 t}
\end{aligned}
$$

\subsection{Metodologi Penelitian}

Data jumlah perceraian yang digunakan adalah data time series dalam rata-rata bulanan di Kota Pekanbaru beserta data faktor-faktor terjadi perceraian, seperti faktor ekonomi, tidak harmonis dan tidak bertanggung jawab dalam rata-rata bulanan dari Tahun 2014-2018. Dalam analisis data menggunakan model vector autoregressive (VAR), dengan langkah-langkah pembentukan model sebagai berikut:

a. Uji Stasioneritas Data

Uji kestasioneran data dapat dilakukan dengan melihat plot data aktual, plot ACF dan plot PACF serta uji unit root.

b. Menentukan Lag VAR

Dalam penentuan panjang Lag optimal pada model VAR dapat menggunakan pengujian Akaike Information Criterion (AIC), Schwarz Information Criterion (SIC) dan Hannan-Quinn Information Criterion (HQ). Ukuran yang digunakan dalam menguji lag optimal pada model VAR dapat menggunakan persamaan sebagai berikut :

Akaike Information Criterion (AIC) : $-2\left(\frac{1}{T}\right)+2(k+T)$ 
Schwarz Information Criterion (SIC) : $-2\left(\frac{1}{T}\right)+k \frac{\log (T)}{T}$

Hannan-Quinn Information Criterion (HQ) : $-2\left(\frac{1}{T}\right)+2 k \frac{\log (T)}{T}$

c. Uji Kausalitas Granger

Analisis hubungan sebab akibat (kausalitas) antar variabel dalam model VAR dinamakan dengan uji kausalitas Granger, uji ini dapat menggunakan persamaan sebagai berikut :

1. Persamaan unrestricted

$$
Y_{t}=\sum_{i=1}^{p} \alpha_{i} Y_{t-i}+\sum_{i=1}^{p} \beta_{i} X_{t-i}+\varepsilon_{1 t}
$$

2. Persamaan restricted

$$
Y_{t}=\sum_{i=1}^{p} \alpha_{i} Y_{t-i}+\varepsilon_{2 t}
$$

d. Estimasi Parameter

Metode kuadrat terkecil (ordinary least square) merupakan salah satu metode yang dapat digunakan untuk mengestimasi parameter model. Pada model VAR ini juga menggunakan metode kuadrat terkecil (ordinary least square) dengan menentukan turunan fungsi terhadap parameter-parameter model dengan cara meminimumkan jumlah kuadrat galatnya [3].

e. Uji Kelayakan Model

Setelah model diperoleh, perlu dilakukan pengujian terhadap kelayakan model, apakah model dapat digunakan untuk peramalan pada waktu yang akan dating. Pada model VAR ini menggunakan uji Portmanteau untuk uji kelayakan model. Berikut adalah persamaan dari uji Portmanteau tersebut [4] :

$$
Q=T \sum_{i=1}^{p} \operatorname{tr}\left(R_{i}^{T} R_{e}^{-1} R_{i} R_{e}^{-1}\right)
$$

kriteria pengambilan keputusan dilakukan dengan membandingkan nilai $Q$ dengan nilai chi-square, $H_{0}$ diterima jika nilai $Q<$ chi-square atau $p$-value $>\alpha$ yang berarti error tidak ada autokorelasi begitu juga sebaliknya.

f. Peramalan

Peramalan merupakan kegiatan untuk memperkirakan apa yang akan terjadi pada masa yang akan datang. Peramalan dapat dilakukan melalui 3 tahap yaitu data training, data testing dan peramalan untuk waktu yang akan datang. Pengujian akurasi hasil peramalan dapat menggunakan uji MAPE.

\section{Hasil dan Pembahasan}

\subsection{Gambaran Umum Jumlah Narapidana kelas II A Kota Pekanbaru}

1. Statistik Deskriptif Jumlah Perceraian, Faktor Ekonomi, Tidak Harmonis dan Tidak Bertanggung Jawab di Kota Pekanbaru

Data yang digunakan dalam penelitian ini adalah data jumlah perceraian, faktor ekonomi, tidak harmonis dan tidak bertanggung jawab dalam rata-rata bulanan dari Tahun 2014-2018 Analisis deskriptif untuk data jumlah perceraian, faktor ekonomi, tidak harmonis dan tidak bertanggung jawab dapat dilihat pada Tabel 1. berikut: 
Tabel 1. Statistik Deskriptif Jumlah Perceraian, Faktor Ekonomi, Tidak Harmonis dan Tidak Bertanggung Jawab di Kota Pekanbaru

\begin{tabular}{|l|c|c|c|c|c|}
\hline \multicolumn{1}{|c|}{ Variabel } & $\begin{array}{c}\text { Observasi } \\
\text { (N) }\end{array}$ & Mean & Median & Maximum & Minimum \\
\hline Perceraian & 60 & 143,42 & 143,5 & 214 & 53 \\
\hline Faktor Ekonomi & 60 & 17,48 & 19 & 41 & 2 \\
\hline Faktor Tidak Harmonis & 60 & 60,68 & 61,5 & 157 & 8 \\
\hline $\begin{array}{l}\text { Faktor Tidak } \\
\text { Bertanggung Jawab }\end{array}$ & 60 & 16,62 & 16,5 & 47 & 4 \\
\hline
\end{tabular}

\section{Pembentukan Model VAR}

Dalam membentuk model vector autoregressive (VAR) untuk prediksi data jumlah perceraian beserta faktor-faktor yang mempengaruhinya harus mengikuti 6 tahap, yaitu sebagai berikut :

a. Uji Stasioneritas Data

Berikut plot data aktual untuk melihat kestasioneran data jumlah perceraian, faktor ekonomi, tidak harmonis dan tidak bertanggung jawab Kota Pekanbaru mulai Januari 2014 Desember 2018 yaitu :

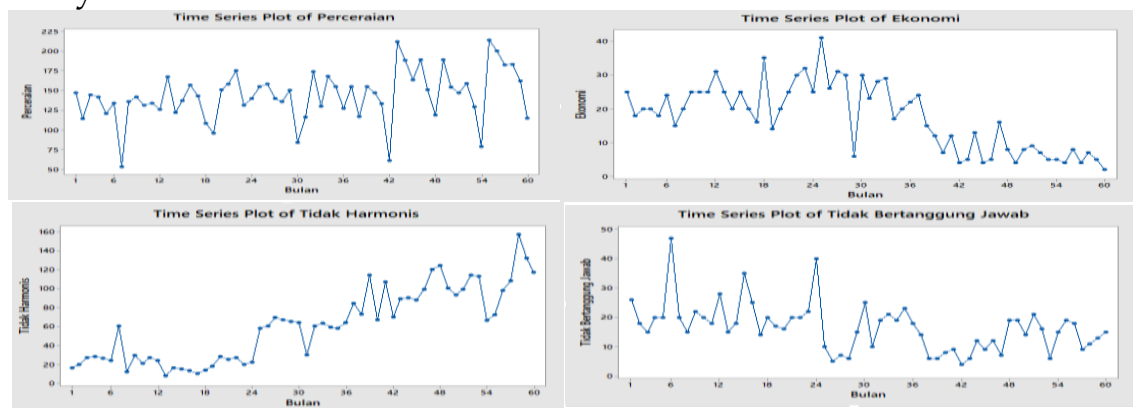

Gambar 1. Plot Data Aktual Jumlah Perceraian, Faktor Ekonomi, Tidak Harmonis dan Tidak Bertanggung Jawab

Berdasarkan Gambar 1. Dapat dilihat bahwa plot data aktual untuk jumlah perceraian, faktor ekonomi, tidak harmonis dan tidak bertanggung jawab belum memenuhi syarat kestasioneran data karena rata-rata maupun varian tidak bergerak secara konstan, untuk itu perlu dilakukan differencing. Hasil differencing pertama plot data aktual untuk jumlah perceraian, faktor ekonomi, tidak harmonis dan tidak bertanggung jawab sebagai berikut :

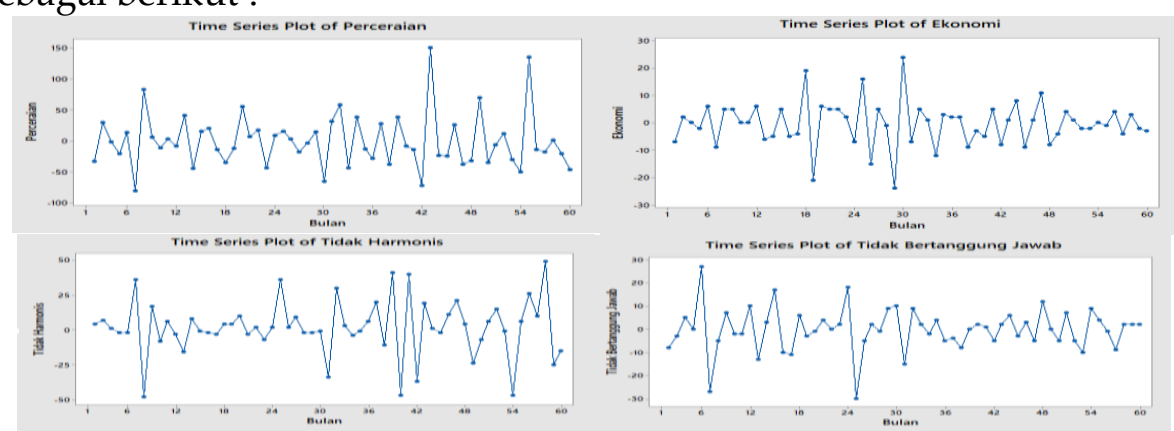

Gambar 2. Hasil Differencing Pertama Plot Data Aktual Jumlah Perceraian, Faktor Ekonomi, Tidak Harmonis dan Tidak Bertanggung Jawab 
Berdasarkan dari hasil differencing pertama untuk plot data aktual data jumlah perceraian, faktor ekonomi, tidak harmonis dan tidak bertanggung jawab adalah data yang stasioner. Selanjutnya kestasioneran data dapat dilihat melalui plot ACF dan PACF, yaitu sebagai berikut :

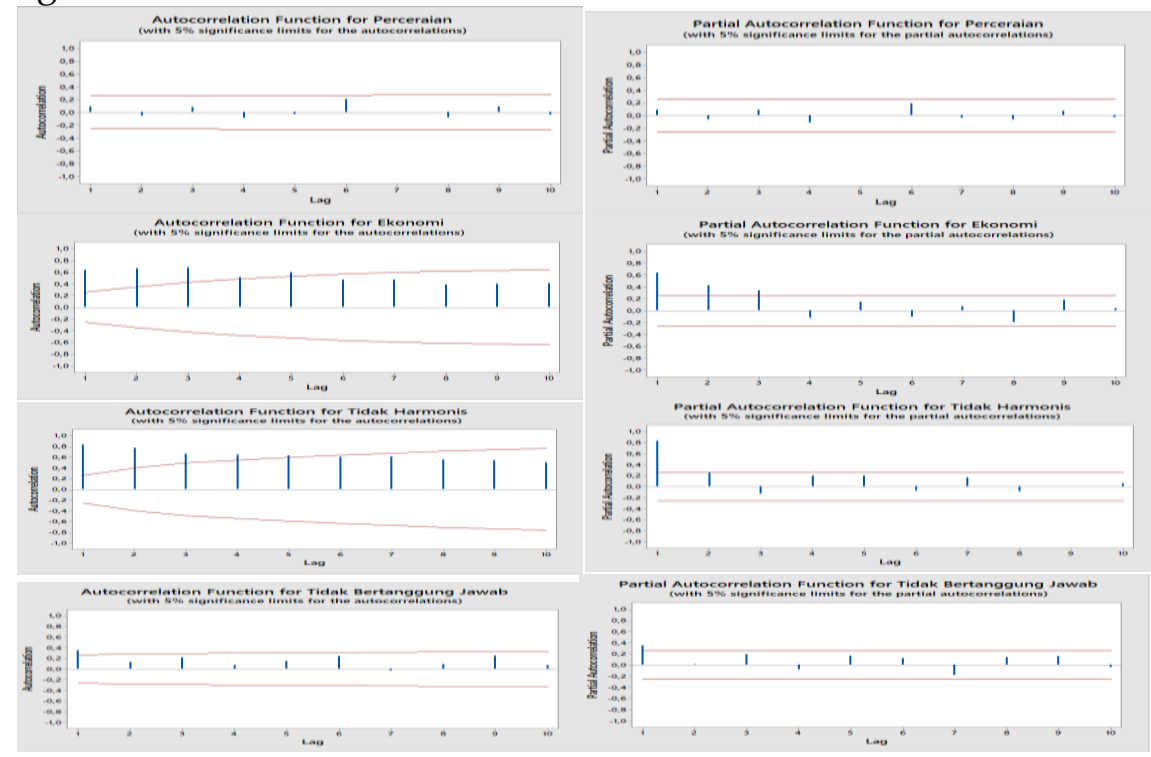

Gambar 3. Plot ACF dan Plot PACF Jumlah Perceraian, Faktor Ekonomi, Tidak Harmonis dan Tidak Bertanggung Jawab

Berdasarkan Gambar 3. Dapat dilihat bahwa plot ACF dan PACF data jumlah perceraian, faktor ekonomi, tidak harmonis dan tidak bertanggung jawab tidak stasioner, karena lag-lag pada fungsi autokorelasi tidak turun secara eksponensial. untuk itu perlu dilakukan differencing. Hasil differencing pertama plot ACF dan PACF data jumlah perceraian, faktor ekonomi, tidak harmonis dan tidak bertanggung jawab sebagai berikut:

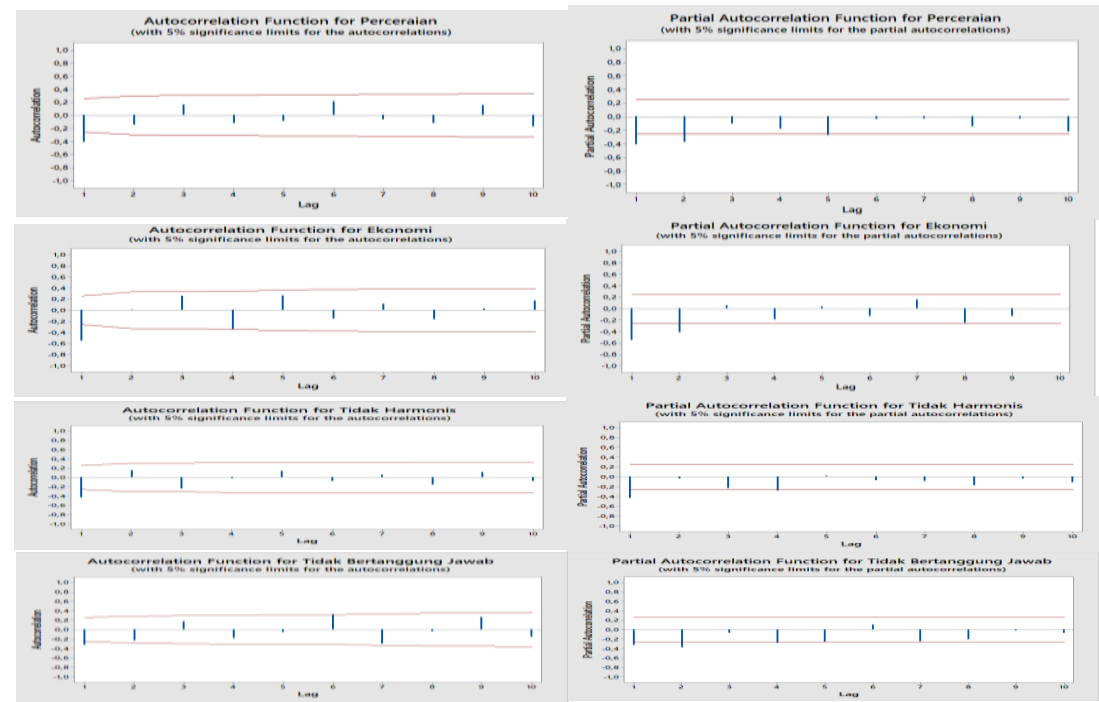

Gambar 4. Hasil Differencing Pertama Plot ACF dan Plot PACF Jumlah Perceraian, Faktor Ekonomi, Tidak Harmonis dan Tidak Bertanggung Jawab 
Berdasarkan Gambar 4. menunjukkan bahwa data jumlah perceraian, faktor ekonomi, tidak harmonis dan tidak bertanggung jawab sudah dikatakan cenderung stasioner dikarenakan untuk setiap lag pada plot ACF menyusut menuju nol secara eksponensial dan PACF terlihat bahwa nilainya terpotong pada lag tertentu.

Berdasarkan dari hasil differencing pertama untuk plot data aktual, plot ACF dan PACF data jumlah perceraian, faktor ekonomi, tidak harmonis dan tidak bertanggung jawab adalah data yang stasioner, maka dapat disimpulkan bahwa data faktor tidak bertanggung jawab stasioner pada tingkat differencing pertama.

b. Menentukan Lag VAR

Setelah diketahui keseluruhan data sudah stasioner, tahap selanjutnya adalah menentukan panjang lag optimal yang akan digunakan dalam model vector autoregressive (VAR). Berdasarkan software Eviews didapatkan panjang lag optimal seperti pada Tabel 2 berikut:

Tabel 2. Panjang Lag Optimal

\begin{tabular}{|c|c|c|c|}
\hline Lag & AIC & SIC & HQ \\
\hline 0 & 33,64478 & 33,79212 & 33,70160 \\
\hline 1 & 33,01966 & $33,75632^{*}$ & 33,30376 \\
\hline 2 & $32,79177^{*}$ & 34,11776 & $33,30316^{*}$ \\
\hline 3 & 32,98063 & 34,89594 & 33,71929 \\
\hline 4 & 32,92786 & 35,43251 & 33,89381 \\
\hline 5 & 32,82866 & 35,92263 & 34,02188 \\
\hline
\end{tabular}

Berdasarkan Tabel 2. dapat dilihat bahwa jumlah nilai AIC, SIC, dan HQ yang terkecil diantara berbagai lag yang diajukan berada pada lag 2. Sehingga kita dapat mengetahui bahwa lag optimal yang digunakan untuk model vector autoregressive (VAR) ialah pada lag 2 atau model VAR(2).

c. Uji Kausalitas Granger

Setelah didapat panjang lag optimal, langkah selanjutnya adalah menguji kausalitas Granger. Uji kausalitas Granger dilakukan untuk melihat ada atau tidak hubungan searah atau timbal balik antar variabel. Berikut hasil uji kausalitas Granger menggunakan software Eviews dapat dilihat pada Tabel 3. yaitu:

Tabel 3. Uji Kausalitas Granger

\begin{tabular}{|c|c|c|c|c|}
\hline No & Hipotesis & Obs & F-Statistik & P-Value \\
\hline 1 & $\begin{array}{l}\text { EKO tidak mempengaruhi PCR } \\
\text { PCR tidak mempengaruhi EKO }\end{array}$ & 58 & $\begin{array}{l}1,70067 \\
1,83298\end{array}$ & $\begin{array}{l}0,1924 \\
0,1699\end{array}$ \\
\hline 2 & $\begin{array}{l}\text { TH tidak mempengaruhi PCR } \\
\text { PCR tidak mempengaruhi TH }\end{array}$ & 58 & $\begin{array}{l}5,04491 \\
2,11562\end{array}$ & $\begin{array}{l}0,0099 \\
0,1306\end{array}$ \\
\hline 3 & $\begin{array}{l}\text { TBJ tidak mempengaruhi PCR } \\
\text { PCR tidak mempengaruhi TBJ }\end{array}$ & 58 & $\begin{array}{l}1,01100 \\
0,30901\end{array}$ & $\begin{array}{l}0,3708 \\
0,7355\end{array}$ \\
\hline 4 & $\begin{array}{l}\text { TH tidak mempengaruhi EKO } \\
\text { EKO tidak mempengaruhi TH }\end{array}$ & 58 & $\begin{array}{l}0,46145 \\
7,11948\end{array}$ & $\begin{array}{l}0,6329 \\
0,0018\end{array}$ \\
\hline 5 & $\begin{array}{l}\text { TBJ tidak mempengaruhi EKO } \\
\text { EKO tidak mempengaruhi TBJ }\end{array}$ & 58 & $\begin{array}{l}1,34380 \\
1,12881\end{array}$ & $\begin{array}{l}0,2696 \\
0,3311\end{array}$ \\
\hline 6 & $\begin{array}{l}\text { TBJ tidak mempengaruhi TH } \\
\text { TH tidak mempengaruhi TBJ }\end{array}$ & 58 & $\begin{array}{l}4,70352 \\
0,08428 \\
\end{array}$ & $\begin{array}{l}0,0132 \\
0,9193 \\
\end{array}$ \\
\hline
\end{tabular}

Berdasarkan uji kausalitas Granger diatas dapat dilihat bahwa yang mempunyai kausalitas antar variabel yaitu perceraian dipengaruhi tidak harmonis, tidak harmonis dipengaruhi factor ekonomi, tidak harmonis dipengaruhi tidak bertanggung jawab.

d. Estimasi Parameter 
Pada langkah ini merupakan langkah pengestimasian parameter untuk model VAR. Pada langkah kedua sudah diperoleh panjang lag yaitu 2 yang terdiri dari 4 variabel sehingga model yang dihasilkan untuk diestimasi adalah VAR(2). Adapun persamaan dari model VAR(2) adalah sebagai berikut :

$$
\begin{aligned}
P C R_{t}= & \alpha_{10}+\alpha_{11} P C R_{t-1}+\alpha_{12} P_{C R_{t-2}}+\alpha_{13} E K O_{t-1}+\alpha_{14} E K O_{t-2}+\alpha_{15} T H_{t-1}+\alpha_{16} T H_{t-2} \\
& +\alpha_{17} T B J_{t-1}+\alpha_{18} T B J_{t-2} \\
E K O_{t}= & \alpha_{20}+\alpha_{21} P C R_{t-1}+\alpha_{22} P C R_{t-2}+\alpha_{23} E K O_{t-1}+\alpha_{24} E K O_{t-2}+\alpha_{25} T H_{t-1}+\alpha_{26} T H_{t-2} \\
& +\alpha_{27} T B J_{t-1}+\alpha_{28} T B J_{t-2} \\
T H_{t}= & \alpha_{30}+\alpha_{31} P C R_{t-1}+\alpha_{32} P C R_{t-2}+\alpha_{33} E K O_{t-1}+\alpha_{34} E K O_{t-2}+\alpha_{35} T H_{t-1}+\alpha_{36} T H_{t-2} \\
& +\alpha_{37} T B J_{t-1}+\alpha_{38} T B J_{t-2} \\
T B J_{t}= & \alpha_{40}+\alpha_{41} P C R_{t-1}+\alpha_{42} P C R_{t-2}+\alpha_{43} E K O_{t-1}+\alpha_{44} E K O_{t-2}+\alpha_{45} T H_{t-1}+\alpha_{46} T H_{t-2} \\
& +\alpha_{47} T B J_{t-1}+\alpha_{48} T B J_{t-2}
\end{aligned}
$$

dimana:

$P C R_{t} \quad$ : Perceraian pada waktu $t$

$E K O_{t} \quad$ : Ekonomi pada waktu $t$

$\mathrm{TH}_{t} \quad$ : Tidak harmonis pada waktu $t$

$\boldsymbol{T B J}_{\boldsymbol{t}}$ : Tidak bertanggung jawab pada waktu $t$

Hasil estimasi parameter didapatkan dengan menggunakan software Eviews. Hasil estimasi parameter model VAR(2) dapat dilihat dalam Tabel 4. berikut ini:

Tabel 4. Estimasi Parameter Model VAR(2)

\begin{tabular}{|c|c|c|c|c|c|c|c|c|}
\hline No & Parameter & Koefisien & No & Parameter & Koefisien & No & Parameter & Koefisien \\
\hline 1 & $\alpha_{10}$ & 2,207616 & 13 & $\alpha_{23}$ & $-0,778642$ & 25 & $\alpha_{36}$ & 0,021597 \\
\hline 2 & $\alpha_{11}$ & $-0,552667$ & 14 & $\alpha_{24}$ & $-0,383407$ & 26 & $\alpha_{37}$ & 0,163071 \\
\hline 3 & $\alpha_{12}$ & $-0,351078$ & 15 & $\alpha_{25}$ & $-0,077697$ & 27 & $\alpha_{38}$ & $-0,087788$ \\
\hline 4 & $\alpha_{13}$ & 0,221284 & 16 & $\alpha_{26}$ & $-0,093773$ & 28 & $\alpha_{40}$ & 0,299790 \\
\hline 5 & $\alpha_{14}$ & 0,678119 & 17 & $\alpha_{27}$ & $-0,044356$ & 29 & $\alpha_{41}$ & $-0,023241$ \\
\hline 6 & $\alpha_{15}$ & $-0,616668$ & 18 & $\alpha_{28}$ & $-0,082257$ & 30 & $\alpha_{42}$ & 0,013442 \\
\hline 7 & $\alpha_{16}$ & $-0,220024$ & 19 & $\alpha_{30}$ & 2,388377 & 31 & $\alpha_{43}$ & $-0,191169$ \\
\hline 8 & $\alpha_{17}$ & $-0,490852$ & 20 & $\alpha_{31}$ & 0,125188 & 32 & $\alpha_{44}$ & $-0,035241$ \\
\hline 9 & $\alpha_{18}$ & 0,196570 & 21 & $\alpha_{32}$ & 0,048156 & 33 & $\alpha_{45}$ & $-0,109314$ \\
\hline 10 & $\alpha_{20}$ & $-0,282009$ & 22 & $\alpha_{33}$ & 0,063444 & 34 & $\alpha_{46}$ & $-0,113358$ \\
\hline 11 & $\alpha_{21}$ & 0,019014 & 23 & $\alpha_{34}$ & 0,570368 & 35 & $\alpha_{47}$ & $-0,498647$ \\
\hline 12 & $\alpha_{22}$ & 0,016852 & 24 & $\alpha_{35}$ & $-0,413708$ & 36 & $\alpha_{48}$ & $-0,410505$ \\
\hline
\end{tabular}

Berdasarkan hasil estimasi, dapat dibuat dalam bentuk model VAR (2) sebagai berikut :

$$
\begin{aligned}
\text { PCR }_{t}= & 2,207616-0,552667 P_{C R}-0,351078 P C R_{t-2}+0,221284 E K O_{t-1}+ \\
& 0,678119 E K O_{t-2}-0,616668 T H_{t-1}-0,220024 T H_{t-2}-0,490852 T B J_{t-1}+0,196570 T B J_{t-2} \\
E K O_{t}= & -0,282009+0,019014 P_{C R_{t-1}}+0,016852 P_{C R}-0,778642 E K O_{t-1}-
\end{aligned}
$$




$$
\begin{aligned}
& 0,383407 E K O_{t-2}-0,077697 T H_{t-1}-0,093773 T H_{t-2}-0,044356 T B J_{t-1}-0,082257 T B J_{t-2} \\
T H_{t}= & 2,388377+0,125188 P C R_{t-1}+0,048156 P C R_{t-2}+0,063444 E K O_{t-1}+ \\
& 0,570368 E K O_{t-2}-0,413708 T H_{t-1}+0,021597 T H_{t-2}+0,163071 T B J_{t-1}-0,087788 T B J_{t-2} \\
T B J_{t}= & 0,299790-0,023241 P C R_{t-1}+0,013442 P_{C R} R_{t-2}-0,191169 E K O_{t-1}- \\
& 0,035241 E K O_{t-2}-0,109314 T H_{t-1}-0,113358 T H_{t-2}-0,498647 T B J_{t-1}-0,410505 T B J_{t-2}
\end{aligned}
$$

Persamaan (14), (15), (16) dan (17) dapat dibentuk ke dalam bentuk matriks seperti berikut ini:

$$
\begin{aligned}
& {\left[\begin{array}{c}
P C R_{t} \\
E K O_{t} \\
T H_{t} \\
T B J_{t}
\end{array}\right]=\left[\begin{array}{c}
2,207616 \\
-0,282009 \\
2,388377 \\
0,299790
\end{array}\right]+\left[\begin{array}{cccccccc}
-0,552667 & -0,351078 & 0,221284 & 0,678119 & -0,616668 & -0,220024 & -0,490852 & 0,196570 \\
0,019014 & 0,016852 & -0,778642 & 0,383407 & -0,077697 & -0,093773 & -0,044356 & -0,082257 \\
0,125188 & 0,048156 & 0,063444 & 0,570368 & -0,413708 & 0,021597 & 0,163071 & 0,087788 \\
-0,023241 & 0,013442 & -0,191169 & -0,035241 & -0,109314 & -0,113358 & -0,498647 & -0,410505
\end{array}\right] } \\
& {\left[\begin{array}{c}
P C R_{t-1} \\
P C R_{t-2} \\
E K O_{t-1} \\
E K O_{t-2} \\
T H_{t-1} \\
T H_{t-2} \\
T B J_{t-1} \\
T B J_{t-2}
\end{array}\right] }
\end{aligned}
$$

e. Uji Kelayakan Model

Berdasarkan langkah pertama pada uji stasioneritas telah menunjukkan bahwa data sudah stasioner, selanjutnya memeriksa residual model mengikuti proses white noise yang berarti residual harus independen (tidak berkorelasi) menggunakan uji Portmanteau. Berdasarkan Uji ini dilakukan dengan bantuan perangkat lunak yaitu software Eviews. Diperoleh hasil sebagai berikut:

Tabel 5. Hasil Uji Portmanteau

\begin{tabular}{|c|c|c|c|c|c|}
\hline Lags & Q-Stat & Prob. & Lags & Q-Stat & Prob. \\
\hline 1 & 2,857683 & NA $^{*}$ & 6 & 78,25090 & 0,5345 \\
\hline 2 & 12.43140 & NA $^{*}$ & 7 & 93,81174 & 0,5442 \\
\hline 3 & 35,06733 & 0,3072 & 8 & 99,29807 & 0,7990 \\
\hline 4 & 59,92462 & 0,1159 & 9 & 117,8334 & 0,7294 \\
\hline 5 & 73,72096 & 0,1901 & 10 & 131,7824 & 0,7586 \\
\hline
\end{tabular}

Berdasarkan Tabel 5. diatas, terlihat bahwa hingga lag ke sepuluh, tidak ada komponen autokorelasi yang signifikan pada tingkat kesalahan $5 \%$, semua $p$-value > 0,05. Sehingga menunjukkan bahwa error tidak ada autokorelasi.

\section{f. Peramalan}

Setelah dilakukan uji kelayakan model dengan menggunakan uji Portmanteau, yang menyatakan bahwa model VAR(2) sudah layak digunakan untuk melakukan prediksi pada waktu yang akan datang. Hasil peramalan jumlah perceraian pada tahap training, testing dan peramalan bulan Januari 2019 sampai Desember 2020 akan disajikan dalam bentuk grafik pada Gambar 5 berikut : 


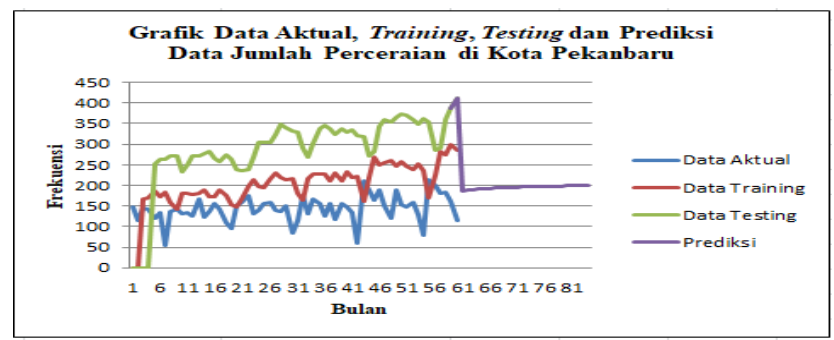

Gambar 5. Grafik Peramalan Jumlah Perceraian

Berdasarkan Gambar 5. dapat kita lihat bahwa hasil prediksi data jumlah perceraian di Kota Pekanbaru pada bulan Januari 2019 hingga Desember 2020 mengalami peningkatan yang tidak berbeda jauh dari bulan sebelumnya untuk Tahun 2019 sampai 2020. Hasil peramalan pada data training secara umum mendekati data aktual, sedangkan pada data testing hasil peramalan kurang mendekati data aktual. Hal ini dikarenakan data yang digunakan untuk peramalan data testing menggunakan unsur data training. Nilai MAPE yang diperoleh adalah 47,7648 \%, yang artinya model VAR(2) memberikan hasil yang wajar dalam peramalan jumlah perceraian di Kota Pekanbaru.

\section{Kesimpulan}

Berdasarkan hasil pembahasan model VAR yang didapat adalah model VAR(2). Berdasarkan hasil uji kausalitas Granger yang telah dilakukan menunjukkan bahwa yang mempunyai kausalitas antar variabel yaitu jumlah perceraian mempengaruhi faktor tidak harmonis, faktor tidak harmonis mempengaruhi faktor ekonomi, dan faktor tidak harmonis mempengaruhi faktor tidak bertanggung jawab. Hasil peramalan pada data training secara umum mendekati data aktual, sedangkan pada data testing hasil peramalan kurang mendekati data aktual. Hal ini dikarenakan data yang digunakan untuk peramalan data testing menggunakan unsur data training. Hasil peramalan data jumlah perceraian di Kota Pekanbaru mulai Januari 2019 sampai dengan desember 2020 mengalami peningkatan yang tidak berbeda jauh dari bulan-bulan sebelumnya. Nilai MAPE yang diperoleh adalah 47,7648 \%, yang artinya model VAR(2) memberikan hasil yang wajar dalam peramalan jumlah perceraian di Kota Pekanbaru.

\section{Daftar Pustaka}

[1] N. Mubarok, “Kriminologi Dalam Perspektif Islam,” p. 112, 2017.

[2] G. M. Robinson, "Time Series Analysis," Int. Encycl. Hum. Geogr., pp. 285-293, 2009, doi: 10.1016/B978-008044910-4.00546-0.

[3] C. Chatfield, TIME-SERIES FORECASTING. 2000.

[4] G. Casella, Springer Texts in Statistics. .

[5] A. P. Desvina, J. Matematika, F. Sains, T. Uin, and S. Riau, "Penerapan Metode BoxJenkins Untuk Memprediksi Jumlah Mahasiswa Universitas Islam Negeri Suska Riau," J. Sains, Teknol. dan Ind., vol. 12, no. 1, pp. 80-89, 2014, [Online]. Available: http://ejournal.uin-suska.ac.id/index.php/sitekin/article/view/777.

[6] H. J. Bierens and H. Song, "Semi-Nonparametric Estimation of First-Price Auctions Models with Auction-Speci c Heterogeneity using Simulated Method of Moments," no. January, pp. 1-24, 2007.

[7] E. Parzen, “Long Memory of Statistical Time Series Modeling,” 2004. 
[8] H. W. Mun, T. K. Lin, and Y. K. Man, “FDI and Economic Growth Relationship : An Empirical Study on Malaysia," pp. 11-18, 2008.

[9] T. Bengtsson and J. E. Cavanaugh, "An Improved Akaike Information Criterion for State - Space Model Selection."

[10] S. Hu, "Akaike Information Criterion," pp. 1-19, 2007.

[11] P. K. Ã and G. Glatting, "ARTICLE IN PRESS Model selection for time-activity curves: The corrected Akaike information criterion and the F-test," vol. 19, pp. 200206, 2009, doi: 10.1016/j.zemedi.2009.05.003. 